\title{
Zło trzeba dobrem nakrywać O kulturowej, narodowej i religijnej zagładzie Tybetańczyków
}

\section{Pamięć i uczestniczenie}

Lata temu spotkałam młodego mnicha tybetańskiej tradycji sakja. Dużo rozmawialiśmy, także o rozumieniu pojęć, które budują nasze myślenie.

- A pamięć? Do czego jej potrzebujemy? - zapytałam.

- Żeby rozróżniać nasze dobre i złe uczynki. I żeby móc wiedzieć, których unikać, a które mnożyć - odpowiedział Dagpo Rinpocze.

A może także dlatego trzeba pamiętać, żeby wywodzić inne wnioski? Żeby pamięć nie tylko nas usprawiedliwiała, a rozpacz i bunt wobec minionego syciły, ale - żeby pamięć wzbudzała naszą niezgodę, nasz sprzeciw wobec zła teraźniejszego.

Z porównania: jak gorliwie przeżywamy tragedie minione, a jak bardzo obojętni jesteśmy na to, co teraz woła o pomoc - wynika tylko bezradność i rozczarowanie człowieczą niemocą. Dlaczego jesteśmy tacy empatyczni wobec przeszłości? Tak bardzo dobrze wiemy, jak należało się zachować, a jaka postawa była niemoralna. (Marek Edelman mówił mi wiele razy, różnymi słowami, że wtedy, w getcie, była inna moralność i nikt z nas, kto tam nie był, nie może mieć o niej najmniejszego pojęcia).

I czemu, dlaczego nasze zaangażowanie w to, co złe teraz, nasza pomoc dla ofiar czasu teraźniejszego są tak płytkie, tak nieskuteczne? Najłatwiej znajdujemy słowa pełne oburzenia i potępienia. Przekładamy dramatyczne zdarzenia, które dzieją się obok nas, na „rozumienie” cudzej krzywdy, współczujemy emocjami, i... nadal przyzwalamy na zło. Jak możemy pomóc, jak możemy zło dobrem 
nakryć? Każda i każdy z nas - cóż możemy sprawczego czynić? Nie wiemy, nie umiemy?

Ludobójstwa, zbrodnie przeciwko ludzkości, masowe mordy, masakry wszystkim im patronują państwa i narody, a uczestniczą w nich zbiorowości uwikłane w zło na mocy jakiegoś istniejącego w ich systemach „prawa”. Wszystkie one odbyły się i odbywają się w imię wyższości jednych nad drugimi. Wszystkie one powstają z ludzkiego przyzwolenia na czynienie zła. Jeszcze raz: zbiorowe czynienie zła jest sankcjonowane "prawem” wewnętrznym, a towarzyszą temu pozorny sprzeciw i faktyczna obojętność zewnętrzna.

Przyjrzyjmy się sobie. Jest rok 2019. Ludobójstwo w sudańskim Darfurze trwa od 2003. Muzułmańscy Rohingja w buddyjskim - z nazwy - Mjanmarze palą się $\mathrm{w}$ swoich wioskach, giną $\mathrm{w}$ drodze ucieczki. Zbrodnie na jazydach, chrześcijanach i szyitach w Iraku oraz Syrii trwają i przerażają od lat... International community wydaje deklaracje i oświadczenia, społeczność międzynarodowa potępia, buduje obozy dla uchodźców i niewielu wpuszcza do swojej local community.

Czym jest więc (nie)wrażliwość na Aleppo wobec (nad)wrażliwości na zagładę Żydów? Przejmują nas, i tylko przejmują, zdjęcia zagłodzonych dzieci z getta warszawskiego 1942 roku. Przejmują nas, i tylko przejmują, zdjęcia oszalałych matek, uciekających z dziećmi przed zbrodnią w Iraku, Syrii, Darfurze, Mjanmarze...

Czym jest więc nasza osobność w bezpiecznym świecie wobec osobności tych z nas, którzy teraz są ofiarami ludzkiego barbarzyństwa? Czy nie jest ona etyczną hipokryzją albo może raczej zwykłym tchórzostwem? Najprościej: czy nie jest ona zwyczajnie moralnym kłamstwem? Bo jeśli nie jest to kłamstwo, to przestańmy się jedynie „przejmować” tym, co wokół nas. Przestańmy jedynie o tym mówić. Nie zgadzajmy się na zło. Prawdziwie.

Rozumiem potrzebę wspólnego przeżywania przeszłości. Znam zbiorowe próby rozpoznawania strony ofiar i oprawców. Słyszę ich deklaracje solidarności z prześladowanymi... Wołam, że to nie wystarcza. Nie umniejsza zła obecnego teraz w świecie. To jest reakcja zrodzona w komforcie, która nie ma siły sprawczej. Jest, naturalnie, potrzebna i przydatna, ale nie jako pierwsza i... najczęściej jedyna.

Więc gdzie siły szukać? W determinacji sprzeciwu wobec zła, które się dzieje. Sprzeciwu wobec zła pojedynczego przede wszystkim - bo to jest w zasięgu naszej, indywidualnej, mocy. Ale także czas już odnajdować sprzeciw wobec zła zbiorowego w naszej zbiorowej sile. Czas szukać w sobie i w naszych społecznościach (tych najmniejszych i tej globalnej) świadomości wspólnoty ludzkiej i odpowiedzialności za jej losy. To najpierw czyńmy. A dopiero w drugiej kolejności opłakujmy skutki zła, któremu nie mogliśmy zapobiec.

Tylko „uczestniczenie w” może być, właściwie jest: sprawcze, pomocne, uzdrawiające. Przeciwstawienie się w czasie i miejscu przemocy jest jedyną wartością nieskłamaną. Rozmawianie przy kawie albo przed kamerami o cudzym cierpieniu jest... nietaktowne. O cierpieniu nie należy rozmawiać po, w cudzym cierpieniu 
należy uczestniczyć, nieść pomoc. Być w nim, żeby je nakryć dobrem. Jak Françoise, służąca rodziny Celine Uwineza, kobieta Hutu, która została z mordowanymi Tutsi. I zginęła z wyboru. Życie to największy dar dobra przeciwko złu, który można ofiarować. Tak też ten dar rozumieją Tybetańczycy, którzy w proteście i rozpaczy przeciwko chińskiej przemocy dokonują samospaleń. Największy, ale niejedyny to dar. Uczestniczyć można sprawczo, zło dobrem nakrywając, na wiele sposobów.

\section{Postęp cywilizacyjny?}

W imię prawa. W Iranie publicznie powieszono „przestępcę winnego" relacji homoseksualnej. Tortur nie stosuje się na placach miejskich, ale stosuje się je w ukryciu: w aresztach, więzieniach, obozach - (prawie?) wszędzie na świecie. Nie handluje się już niewolnikami w portach, ale praktykuje się niewolnictwo nowoczesne - wystarczy człowieka porwać, zabrać paszport i zmusić do jakiejkolwiek pracy. No i przede wszystkim - wojny uważa się za uprawnione. Mordowanie drugich uważa się za zasadne - w dziesiątkach różnych sytuacji wyjaśnianych powodami, które formułują użytkownicy przemocy.

Co nam zatem z prawa międzynarodowego? Co nam z tego, że dowódca morderców ze Srebrenicy będzie „osądzony i skazany”? Jak wiemy, perspektywa wymierzonej kary nie powstrzymuje przed czynieniem zła. Powinniśmy wiedzieć także, że istotą rzeczy byłoby sformułowanie takich zasad współistnienia na Ziemi, które nie dozwolą, nie dopuszczą do wojen. A gdyby gdzieś jakaś zaczęła się dziać, to natychmiast inni, strażnicy wspólnego człowieczego porządku, pochwycą strony konfliktu i zatrzymają przemoc. Dopóki będzie istniała zgoda na zabijanie, dopóty ludzka, nasza, przemoc będzie nas, ludzi, przerażała swoimi możliwościami.

\section{Myśl nie z naszego świata}

Mistrzowie myśli buddyjskiej nauczają, że przemoc należy przykrywać empatią. Jak zło dobrem. Że miłość i współczucie winny zastąpić strach i agresję. Szukamy pokoju i szczęścia - i wywołujemy wojny. Ciągle i wszędzie: w relacjach pojedynczych $-\mathrm{z}$ najbliższymi, i w relacjach grupowych $-\mathrm{z}$ tzw. obcymi. Broniąc swego, dajemy sobie prawo do atakowania drugiego. 
- Wojna rozpoczyna się, kiedy zamykamy nasze serce - powtarza mniszka Pema Chödrön, nauczycielka buddyzmu. A potrafimy to czynić z łatwością i często; w sprawach małej wagi i w sprawach najważniejszych. Zamykamy nasze serce zawsze (prawie zawsze?), kiedy czegoś nam brak, kiedy coś chcemy dostać, bo uważamy, że to się nam należy. Albo wtedy zamykamy nasze serce, kiedy nie chcemy czegoś dostawać, kiedy dostane sprawia nam przykrość, ból. W istocie chodzi o to samo: o nasze roszczenia i oczekiwania lub o naszą niechęć do otrzymywanego - to tylko dwa lica tej samej monety, która zwie się „ja i moje”.

Zamykamy nasze serce, bo szukamy w sobie (s)pokoju. Nic bardziej błędnego. Popatrzmy na łańcuch reakcji. Czujemy się dotknięci, obrażeni słowem. Zamykamy nasze serce w obronie, jak sądzimy. Za chwilę doświadczamy konsekwencji zamkniętego serca - pojawia się smutek, żal, przykre myśli nie ustają, cierpimy. Ten stan jest gotowością do podjęcia wojny. I to może być każda wojna - mała, bo między dwojgiem, i wielka, bo między wieloma. Często narzekamy na fundamentalizm innych. A czymże innym, jeśli nie fundamentalizmem, jest zamknięcie naszego serca? Z poczucia skrzywdzenia wyrasta najłatwiej przekonanie o własnym cierpieniu i o winie drugiego. Nasze przekonanie jest podstawowe, fundamentalne. Zamknięte serce zamyka umysł. Zamknięty umysł jest surowy i oskarżycielski.

Oskarżycielski umysł produkuje negatywne myśli. Myśli negatywne wprowadzają w nas stan wojny, niszczą nasz wewnętrzy (s)pokój. Kiedy odnosimy się negatywnościami do drugiego, drugich - stan wojny jest rozpoznawany. Naturalnie, ten drugi, ci drudzy zawsze (prawie zawsze?) budują taki sam mechanizm: $\mathrm{z}$ urażenia, dotknięcia zamykają swoje serce, serce zamyka umysł, który tworzy uzasadnienie dla przekonania o własnej racji, pojawia się postawa obronna, czyli atakująca, i - stan wojny jest jednoznacznie rozpoznawany.

Gdyby tak mieć zdolność ptaka i zobaczyć z wysoka ziemię i wszystkie konflikty - małe i większe wojny... Dostrzeglibyśmy wówczas, że po każdej stronie konfliktu jest ktoś, kto jest przekonany o własnej racji. Gdyby tak mieć zdolność czarodziejki i móc stać się tym drugim... Przekonalibyśmy się wówczas, jak bardzo uparci, fundamentalni w swojej postawie my jesteśmy. Zatem: rozwiązanie dla każdego konfliktu jest w naszej mocy. Wystarczy, że otworzymy serce i z taką dobrą motywacją odniesiemy się do drugiego. Wtedy wprowadzamy (s)pokój w sobie. Wystarczy, że ten drugi otworzy swoje serce i z taką dobrą motywacją odniesie się do nas. Wtedy on także doświadczy (s)pokoju. Stan wojny wewnętrznej i stan wojny między dwojgiem ustanie1. Tak naucza Pema Chödrön, tak uczy myśl buddyjska.

Słyszę reakcję współczesnego judeochrześcijanina: tak, tak, utopia, mrzonka, idealizm, koncept niemożliwy do wypełnienia. Czy naprawdę? A gdyby wyob-

${ }^{1}$ Na podstawie nauk Pemy CHöDrön zawartych w jej książce pt. Practicing Peace in Times of War (Boston-London 2010). 
razić sobie, że ofiara, ten opresjonowany, nie reaguje odwetem (emocjonalnym, fizycznym), a odnosi się do swojego (jak się ofierze wydaje) kata z miłością i współczuciem? Wówczas jedno serce mięknie i zatrzymuje albo przerywa łańcuch przemocy: w sobie samym i w odniesieniu do drugiego. Niesprawiedliwość, przemoc, okrucieństwo - jeśli nie ustają, są co najmniej osłabione.

Antidotum na agresję, a formy ona miewa najróżniejsze, jest... cierpliwość. Najczęściej reagujemy w sposób automatyczny: odpowiadamy słowami i działaniem, które, jak sądzimy, pozwoli nam zrównoważyć ból doznanej agresji. Rzecz się dzieje odwrotna. Przez naszą reakcję wywołujemy więcej agresji i bólu. Możemy nie mieć wpływu na to, co nas dotyka. Ale z pewnością możemy zmienić własny ogląd i rozpuścić naszą agresję. Nasza cierpliwość wymaga odwagi.

I jednej, i drugiej: cierpliwości i odwagi, uczymy się w buddyjskiej praktyce. A zatem. Dostrzeżmy nasze interpretacje, nasze opinie tylko jako takie. Zrezygnujmy z bycia pod ich kontrolą, nie akceptujmy tego, że one naznaczają wszystko, co myślimy i robimy. Silne doznania będą nadal powstawały, ale my możemy rozwinąć taką umiejętność, która pozwoli nam zatrzymać emocje i tym samym zmniejszyć cierpienie.

\section{O Tybecie pod Chińczykami}

Rozmaite znamy definicje ludobójstwa i rozmaite definicje zbrodni przeciwko ludzkości. Te terminy nazywają sytuacje, w których jedni unicestwiają innych: wyniszczane są całe lub części narodów, grup etnicznych, religijnych lub rasowych. I to dziać się może przez fizyczne zabójstwa albo przez stworzenie warunków życia obliczonych na fizyczne wyniszczenie.

Góry, jeziora i drzewa przemawiają do nas swoimi sposobami. Tybetańczycy wierzą, że to są sposoby duchów i bogów, którzy zamieszkują przyrodę. Powiada się, że usłyszeć mogą tylko ci, którzy słyszeć potrafią. Pamięta się, że kiedy Chińczycy zabierali Tybet, wielu ludzi słyszało, jak góry i jeziora hałasowały. To był skowyt rozpaczy, mówią ci, którzy słyszeli i pamiętają. W Tybecie od początku lat 50. odbywa się zagłada kulturowa narodu. Ginie tybetańska mniejszość etniczna pod chińską przemocą sankcjonowaną chińskim prawem. To, co świat obserwuje od ponad 70 lat, jest zbrodnią przeciwko ludzkości.

- „W 1959 sześć mln Tybetańczyków żyło, mieszkało w Tybecie. To jest liczba podatników, których jakimś systemem policzono. Pewnie było nas więcej. Dziś nie ma żadnych liczb. Przecież nie istniejemy w chińskiej administracji jako naród. Istniejemy jako istoty, które trzeba ujarzmić i którym trzeba zmienić tożsamość" - powiedział mi tybetański historyk na uchodźstwie w Indiach².

\footnotetext{
${ }^{2}$ Cytat pochodzi z mojej nowej książki pt. Dalekowysoko (2020).
} 
Poniżej, poprzez omówienie haseł-kluczy, szkicuję podstawową mapę narodowego i kulturowego życia Tybetańczyków - dziś, obecnie.

\section{- Klasztory}

ChRL uważa buddyzm za główne narzędzie w odrywaniu Tybetu od „matki-ojczyzny”. W ostatnich kilkunastu latach Chińczycy zmienili taktykę wobec klasztorów i ich rezydentów. Najczęściej nie demolują już całych budowli buldożerami, jak to czynili w czasie rewolucji kulturalnej ${ }^{3}$. Demolują ich fragmenty. Jak w Larung Gar - największej instytucji buddyjskiej na świecie. Zburzono wiele budynków klasztornych („modernizacja” trwa) i tysiące monastyków zmuszono do odejścia. Podaje się, że między lipcem 2016 a lipcem 2017 zlikwidowano około 4700 schronień i około 5000 mniszek i mnichów musiało zrezygnować ze swojego klasztornego życia.

Urzędnicy państwowi nie prześladują już wszystkich mniszek i mnichów, prześladują tylko wybranych. Najchętniej aresztują nauczycieli: opatów, lamów, rinpoczów. Nowy, z marca 2019, jest zakaz klasztornej nauki języka tybetańskiego, prowadzonej dla dzieci w czasie ich zimowej przerwy szkolnej. Jeśli zakaz zostanie złamany, mnisi - nauczyciele są wyrzucani z klasztoru, a uczniowie i ich rodzice poddawani „treningowi reedukacyjnemu”.

Często niszczone są symbole religijne, zwłaszcza te najstarsze i najcenniejsze, które przetrwały cudem barbarię lat wcześniejszych. Trudno sobie aż taką uporczywość wyobrazić - urzędnicy wydają polecenia świdrowania gór, w których znajdują (się) tsamfuk, groty medytacyjne. W Diru County urzędnicy nakazali zniszczyć każdą stupę i każdy kopiec mane, które zostały zbudowane po 2010.

Wprowadzono zasadę obowiązującą większość klasztorów - nie wolno przyjmować do nowicjatu chłopców poniżej trzynastego roku życia (tradycyjnie rodziny oddają do klasztorów chłopców sześcio-, siedmioletnich). Zakazano także nauczania dzieci z okolicznych wiosek.

Thardoe Gyaltsen był umze, prowadzącym modlitwy, w klasztorze Drong Na w Diru County. W 2013 został aresztowany, a w styczniu 2014 skazany na 18 lat więzienia. Jego przestępstwo polegało na tym, że prowadził zajęcia z języka i kultury tybetańskiej. Uczestnikami byli mnisi i mieszkańcy okolicznych wiosek. Po aresztowaniu klasztor Thardoe Gyaltsena został zamknięty, a mnisi wygnani.

\section{- Przesiedlenia}

Około 40\% etnicznych Tybetańczyków to nomadzi. ChRL prowadzi politykę przesiedleńczą. W konsekwencji: nomadzi, dawniej w pełni samowystarczalni, teraz - pozbawieni swojej ziemi, przesiedlani na nieznany teren, zadłużeni u państwa, bez pracy - są grupą społeczną w upokorzeniu i chorobie.

${ }^{3}$ Dla przypomnienia: ponad 6000 klasztorów zostało całkowicie zniszczonych, a ponad 500000 mniszek i mnichów aresztowano bądź zmuszono do świeckiego życia. 
Na przykład nomadzi z okolic jezior Kyaring i Ngoring, które łączą się z rzeką Machu. Kiedyś żyły tu, na wielkich łąkach, tysiące zwierząt pod ich opieką. Wszystko się zmieniło. Kwieciste łąki ogrodzono, zwierzęta kazano sprzedać do państwowych rzeźni, nomadów zamknięto w betonowych osiedlach. Nie dostali szkoły, opieki medycznej, pracy. (Nie znają chińskiego, nie są uczeni zawodów). Tam, gdzie w rzędach ustawiono betonowe kostki, w których mają żyć, nie ma żadnej świątyni, żadnej stupy, nie ma jednego mnicha, który byłby wsparciem. Szybko skończyły się pieniądze wydziedziczonym, popadli w biedę, rozpacz i alkoholizm. Nie ma dokładnych liczb, są tylko szacunkowe. Przyjmuje się, że dwa miliony nomadów zostało przesiedlonych. A „czyszczenie terenu" trwa.

\section{- Podróżowanie}

Tybetańczyk, który chce wyjechać ze swojej wioski, miasta, musi dostać pisemne pozwolenie z kilku różnych urzędów. W czasie podróży jest przeszukiwany w punktach kontrolnych. Jedne są „stacjonarne” i jest ich sporo, inne są ustawiane wedle potrzeby. Dla przykładu: na odcinku $270 \mathrm{~km}$ między Nagchu County a miastem Diru jest osiem stałych punktów kontrolnych i zawsze kilka dodatkowych, ruchomych. Podróżujący, którzy okazują niezadowolenie z powodu trudu podróży, są bici, pozbawiani prawa jazdy, obciążani karą grzywny, zatrzymywani w areszcie...

\section{- Areszty}

Są zatrzymywani, obciążani wysokimi grzywnami, aresztowani, więzieni, często bez procesu, z rozmaitych przyczyn, przez długie lata. Doświadczają głodu, chorób, przemocy, gwałtów, tortur, wszelkiego upokorzenia.

\section{- Życie społeczne}

Wioski bez klasztorów, bez mnichów, z budami sprzedającymi świeczki i whiskey w plastikowych butelkach, nowe, betonowe miasta bez klasztorów, bez stup. Ludzie w strachu, przygnębieniu, chorobach - bez swojej religii, bez swojego prawa do myślenia. Rodziny $\mathrm{w}$ utracie najbliższych przez przesiedlenia, więzienia, uchodźstwo. Tybetańczycy bez możliwości jakiegokolwiek decydowania o własnym domu, o własnej ziemi, o własnym kraju, o sobie samych.

W styczniu 2018 Lodoe Gyatso, lat 58, rozpoczął kampanię na rzecz pokoju na świecie przed Potalą, pałacem dalajlamów w Lhasie. Odświętnie ubrany, siedząc na ziemi, wzywał do niestosowania przemocy. Gakyi, jego żona, sfilmowała to kilkuminutowe zdarzenie, nim policja aresztowała oboje. Lodoe został skazany na 18 lat, a Gakyi na 2 lata więzienia. Nie wiadomo, gdzie są więzieni. 
Sąd w prefekturze Nagchu odmawia podania informacji. To jest kolejny areszt dla Lodoe Gyatso. W maju 2013 wyszedł z więzienia po 23 latach.

W 2014 Chińczycy nakazali Tybetańczykom wywieszać chińskie flagi z okien ich domów i z okien klasztorów - w ten sposób mieli oni okazać „szacunek dla symbolu i lojalność władzom" w Pekinie. W Diru ponad 1000 osób zaprotestowało - wrzucili flagi do rzeki. Trigyal był jednym z nich. Został aresztowany i skazany na 13 lat. Za wrzucenie chińskiej flagi do rzeki. Wielokrotnie torturowany, zmarł w więzieniu. Właściwie należałoby napisać: został zamordowany.

21 Tybetańczyków skazano na kary od 2 do 6 lat więzienia i wysokie grzywny 28 czerwca 2019. Wszyscy mężczyźni pochodzą z tej samej wioski, z Do Thrang w Shorda. Dwaj, którzy dostali najwyższe wyroki, zostali oskarżeni o mobilizowanie grupy wieśniaków do założenia „komitetu ochrony środowiska, który zakłócał działania rządowe".

Mnich Choeying Khedrup. W 1999 został oskarżony o drukowanie ulotek wzywających do protestu. Lama Bangri Choktrul Rinpocze, założyciel sierocińca w Lhasie, w 2000 został oskarżony o „konspirowanie z kliką Dalaja”. Obaj skazani zostali na karę dożywotniego więzienia.

Lhamo Kyab. Była nauczycielką w Diru, w prefekturze Nagchu, w Centralnym Tybecie. Została uprowadzona przez tajne służby w czerwcu 2008. W styczniu 2010 skazano ją na 15 lat więzienia. Nie podano danych dotyczących zarzutów, procesu i miejsca, w którym jest więziona.

Yeshe Choedron. Emerytowana lekarka, lat 57. Została zatrzymana w marcu 2008 w związku z protestami w Lhasie. 7 listopada 2008 sąd skazał ją na 15 lat więzienia za „rozpowszechnianie informacji zagrażających bezpieczeństwu i interesom państwa". Yeshe Choedron nie otrzymuje zgody na widzenia z dziećmi.

Jampel Wangchuk, Konchok Nyima, Ngawang Choenyi. Trzej mnisi seniorzy klasztoru Drepung. W kwietniu 2008 zostali zatrzymani w związku z marcowymi protestami w Lhasie. Jampel Wangchuk, lat 55, został skazany w 2010 na dożywocie; oskarżenie nie zostało ujawnione. Konchok Nyima, lat 43, skazany w 2010 na 20 lat więzienia; oskarżenie nie zostało ujawnione. Ngawang Choenyi, lat 38, otrzymał wyrok 15 lat więzienia w 2010; oskarżenie nie zostało ujawnione.

Wangdu. Były mnich oraz więzień polityczny, pracownik australijskiego programu przeciwdziałającego HIV/AIDS, został aresztowany w marcu 2008 i skazany na dożywocie z oskarżenia o szpiegostwo. Ostatni raz był widziany w lhaskim szpitalu w 2012.

Norzin Wangmo. Lat ponad 30, pochodząca z Ngaba Trochu County, została skazana na 5 lat więzienia w 2008 za telefoniczne i internetowe przekazywanie poza granice kraju wiadomości na temat sytuacji w Tybecie.

Karma Samdrup. 42 lata, znany filantrop i ekolog, został skazany 24 czerwca 2010 na 15 lat więzienia z oskarżenia o „rabowanie grobów i handel kulturowymi reliktami". 
Phagpa. 27 lat, mężczyzna z Dowa, został skazany na 13 lat więzienia 8 lutego 2013 za „zachęcanie mnicha Dolmy Kyab z klasztoru Dowa i innych do popełnienia samospalenia".

Tashi Paljor. 34-letni mnich z klasztoru Dzongsar w okręgu Dege, został zatrzymany za posiadanie wideo $\mathrm{w}$ telefonie komórkowym. Był torturowany. Zmarł w areszcie w marcu 2014. (Komunikacja cyfrowa w Tybecie jest obserwowana, cenzurowana i blokowana. Chińskie służby aresztują tych, którzy posiadają teksty pisane, wideo, dźwiękowe, uważane za „politycznie wrażliwe”).

19 lipca 2015 nadeszły informacje z anonimowego źródła, że Lobsang Yeshe, więziony w latach 60., także z politycznego oskarżenia, zmarł w więzieniu Chushul w Lhasie. 7 maja 2014 był powtórnie skazany. Karę 2 lat otrzymał za protest przeciwko niszczeniu środowiska naturalnego w rejonie Gyalmo Ngulchu (sprzeciwiał się budowaniu tam i zakładaniu kopalń). Wiadomo, że był bity i torturowany. Jego sześćdziesięcioletnie ciało wyczerpało swe siły życia i Lobsang Yeshe, ojciec ośmiorga dzieci, jedyny żywiciel rodziny, zmarł. Mimo składanych przez rodzinę podań władze nie oddały ciała i tym samym uniemożliwiły pochówek zgodny z rytuałem.

15 sierpnia 2013 Dolma Kyab, lat 32, został skazany na karę śmierci z zawieszeniem na 2 lata. Zarzucono mu, że „zabił swoją żonę i spalił jej ciało, pozorując akt samospalenia”. Okoliczności samospalenia Kunchok Wangmo nie są znane.

Woeker Kyi. Nomadka, około 23 lata, matka czteroletniego chłopca, została zatrzymana 15 sierpnia $2015 \mathrm{w}$ południowo-zachodnim Syczuanie. Kobieta domagała się pozwolenia na powrót Dalajlamy do Tybetu. Nieznane jest miejsce, w którym jest więziona, i nieznany jest wyrok, który zasądzono.

Przypadki tybetańskich więźniów politycznych są, na tyle, na ile to możliwe, monitorowane przez rozmaite fundacje i organizacje lokowane w zachodnim świecie. Od 1955 setki tysięcy Tybetańczyków było więzionych. Podaje się, że po 1959 25\% społeczeństwa przeszło przez areszty, więzienia i obozy (w 2008 aresztowano ponad 10000 ludzi). W Tybecie powstają nowe obozy koncentracyjne. Ostatnio dotarły informacje o trzech budowanych w Tybetańskim Regionie Autonomicznym. Chińczycy nazywają je „reedukacyjnymi przez pracę”. Tybetańczycy coraz częściej mówią o nich „klasztorne gułagi”, bo obozy mają więzić mnichów i mniszki. Nowe gułagi powstają w oddalonych miejscach. (Taką samą politykę edukacji przez przemoc prowadzą Chińczycy w Ujgurskim Regionie Autonomicznym).

Klasztory zostały zniszczone i nawet jeśli niektóre odbudowane - życie w nich jest kontrolowane nakazami i karabinem. W oknach klasztorów muszą wisieć flagi chińskie, a na ścianach thangki z portretami chińskich oficjeli. 
Edukacja klasztorna jest w zasadzie rozbita, świeckie szkoły to chińskie szkoły. Język i kultura tybetańska są przemycane z ryzykiem kary więzienia. Nomadzi, półnomadzi z Centralnego Tybetu, z Amdo i z Khamu pozbawiani ziemi i zwierząt, przenoszeni z namiotów do betonowych domów chińskich miast - tracą wszystko. W swoich namiotach, domach Tybetańczycy przechowują zdjęcia Dalajlamy w ukryciu, bo prawo surowo zabrania. Przesyłają sobie jego nauki na WeChat, modlą się o jego powrót, czasem wykrzykują to marzenie głośno na jakiejś chińskiej ulicy. Za każdą z tych „przewin” dostają wysokie wyroki więzienia. Lhasa, stolica, do niedawna święte miasto wszystkich Tybetańczyków, dziś jest miastem taniego chińskiego handlu, byle jakiej turystyki i dozwolonej prostytucji.

Ziemia Tybetu jest także ofiarą chińskiej przemocy. Rzeki, jeziora, łąki, lasy i góry cierpią. Bezwzględna eksploatacja Wyżyny Tybetańskiej skutkuje destabilizacją całego ekosystemu. Źródła wody dla milionów ludzi tam właśnie się znajdują, a ocieplenie klimatu na Wyżynie odbywa się dwa razy szybciej niż gdziekolwiek indziej na Ziemi. Świadomość znaczenia „tybetańskiego kryzysu” jest bez wątpienia jednym z kluczy do naprawy.

Powyżej w dużym skrócie narysowałam centra cierpienia, przed którymi lub z powodu których jedni Tybetańczycy uszli z Tybetu, inni pozostali tam w rozpaczy, a jeszcze inni godzą się na przymusowe zmiany. Najkrócej: odbywa się staranna próba szybkiej sinizacji Tybetu, kulturowa zagłada Tybetańczyków. Polityka przemocy Chin prowadzi do fizycznego i moralnego wyniszczenia narodu. Jest zagładą (eksterminacją, anihilacją) narodu tybetańskiego. Zagłada kulturowa bywa/może być wstępem do ludobójstwa. Ludobójstwo nie wyrasta z próżni. Jest konsekwencją wcześniejszych działań przemocowych.

\section{Tybetańczycy w samoobronie}

Tybetańczycy nie bronią się przemocą. Nie uczestniczą w złu. Nie mnożą zła. Znajdują swoje pokojowe sposoby protestu i sprzeciwu. I ponoszą za nie najsurowsze kary. A kiedy składają największą ofiarę w imię własnej obrony, kiedy oddają swoje ciało, a w nim to życie - najsurowsze kary dotykają ich bliskich.

Pierwszy w tybetańskiej sprawie spalił się sześćdziesięcioletni Thupten Ngodrup. Wydarzyło się to 27 kwietnia 1998 w Delhi. Przyjechał z Dharamsali z grupą Tybetańskiego Kongresu Młodzieży na „strajk głodowy do śmierci” (ponad 100 osób wpisało się na listę ochotników). Kiedy policja zaatakowała namiot głodujących, Thupten pędem puścił się w kierunku jakiegoś budynku. Zostało to zapisane w obrazie filmowym. A po chwili biegł - gorejący czło- 
wiek - z powrotem w kierunku namiotu. Krzyczał coś o Tybecie i o Dalajlamie. Zatrzymał się, podniósł dłonie jak do modlitwy. W szpitalu był przytomny, milczał. Lekarze ocenili poparzenia na niemal 100 procent. Wieczorem przybył do niego Dalajlama. Thupten chciał się unieść na łóżku, złożył obandażowane dłonie na piersi. Jego Świątobliwość zapytał, czy słyszy. Thupten poruszył głową. Dalajlama powiedział, że nie powinien czuć nienawiści do Chińczyków i że jego czyn sprawi, że świat zauważy Tybet. Około północy Thupten poprosił o włożenie cukierka do ust. Zapytał o sześciu głodujących. Usłyszał, że są w szpitalu. Wyszeptał, że jest szczęśliwy. Thupten umarł tej samej nocy. Sześć dni wcześniej udzielał wywiadu radiu Voice of Tibet. Powiedział wtedy: „oddaję życie za pokój i za mój udręczony naród".

27 lutego 2009 był trzecim dniem Losaru, tybetańskiego Nowego Roku. Władze chińskie zakazały uroczystości Mynlamu, największego święta religijnego. Dwudziestoletni mnich klasztoru Kirti nazywany Tapey (Lobsang Tashi) wyszedł na ulicę w Ngabie i podpalił swoje ciało. Biegł z flagą tybetańską i portretem Jego Świątobliwości, póki ogień nie skruszył jego ciała. Umundurowani i tajniacy strzelali do płonącego. Szesnastu otoczyło leżącego, zawlekli go do samochodu. Tapey zostawił list. Napisał, że podpali się w proteście, bo nic innego uczynić w sprzeciwie nie może. To był pierwszy wypadek samospalenia we współczesnym Tybecie.

Kolejne przypadki są podobne. Choć każdy jest pojedynczy i inny. Jest tych przypadków samospaleń (do 22 października 2019) 165. Człowiek jest zdeterminowany w postanowieniu, pisze list bądź wykrzykuje swoje prośby. (Tak, to nie są żądania). Chińscy paramilitarni ${ }^{4}$ wyrastają obok w minucie, strzelają albo biją pałami płonącą czy płonącego. Wokół gromadzą się rodacy. Odbywa się coś w rodzaju walki o ciało - jeszcze żywe lub już martwe. Wszystko zależy od sił po obu stronach. Czasem udaje się je odbić, rzadko udaje się je ukryć. Zazwyczaj jest wywożone przez służby chińskie i długi czas mija, nim bliscy czegokolwiek się dowiedzą. Władze hołdują $\mathrm{w}$ swych prześladowaniach zasadzie odpowiedzialności zbiorowej. Dlatego kary najczęściej są wymierzane także rodzinom, nauczycielom, sąsiadom, przyjaciołom, klasztorom.

Thich Nhat Hanh, buddyjski mistrz i filozof, w liście do Martina Luthera Kinga w 1965 napisał słowa, które, być może, ułatwią rozumienie niezrozumiałego: „Zachodniemu, chrześcijańskiemu sumieniu trudno było zrozumieć samospalenia wietnamskich mnichów buddyjskich w 1963. Media mówiły wtedy o samobójstwie, lecz w istocie akt ten nim nie jest. Nie jest nawet protestem. Zgodnie z listami, które mnisi zostawiali przed podpaleniem się, ich zamiarem

${ }^{4}$ Członkowie Ludowej Policji Zbrojnej (People’s Armed Police, PAP), chińskiej żandarmerii paramilitarnej, która jest odpowiedzialna za tłumienie wszelkich oznak odrębności - kulturowej, religijnej, społecznej. Działania paramilitarnych w chińskiej propagandzie nazywane są zwalczaniem terroryzmu. 
było jedynie przebudzenie, poruszenie serc ciemiężców i zwrócenie uwagi świata na cierpienia Wietnamczyków"s.

Porównajmy powyższe z zapisem chińsko-tybetańskiej pisarki Oser: „Przekleństwem Tybetańczyków jest nie nadzieja, lecz cisza. Mamy prosty wybór jeśli nie chcemy zostać zniszczeni, musimy ją strzaskać”. "Samospalenia Tybetańczyków to nie samobójstwo, tylko poświęcenie! Nieludzki kolonializm i nikczemna władza pchają w ogień mnichów buddyjskich i świeckich, zmuszając ich do protestów i ofiary. Chiny, Zachód, świat patrzą na ten szalejący pożar, na płonący stos praw człowieka w milczeniu"7.

Tybetańczycy są zdecydowanie przeciwni nazywaniu samospaleń śmierciami samobójczymi. I jasno tłumaczą, dlaczego: samobójstwo jest wynikiem złej, negatywnej motywacji człowieka. Ludzie, którzy palą swoje ciała, kierują się pozytywną motywacją - wołają do świata, żeby dostrzegł i pomógł. Oddają swoje życia, by uczynić życie innych lepszym.

Historie ofiar, ich poświęcenie i ostatnie słowa znane są wielu - krążą po wsiach, w regionie, w całym wielkim kraju jak swoiste apokryfy. I oddziałują na „zwykłych ludzi”, jak ich nazywa Oser. Zmieniają myślenie pojedynczych, a tym samym przeobrażają zbiorowość. W okręgu Darlag postanowiono uczcić oddanie ciała przez Sopyę Rinpocze poprzez zniszczenie narzędzi przemocy. Zebrano tysiące noży, karabinów myśliwskich i naboi. I - zniszczono je wszystkie. (Nie było to jedyne miejsce takiej formy protestu). Coraz częściej słyszy się o ludziach, którzy oddają bron do klasztorów i ślubują nie uczestniczyć w kłótniach, bijatykach, nie kraść i nie czynić krzywdy drugiemu. Przysięgają solidarność ze swoimi siostrami i braćmi.

Lhakar jest także formą świadomego, pokojowego protestu - demonstrowania przywiązania do własnej tradycji i kultury. Biała Środa to dzień szczególnego pamiętania o Dalajlamie i o Tybecie. W lhakar demonstruje się swoją lojalność wobec Jego Świątobliwości i oddanie dla spraw narodowych. Mówi się po tybetańsku - głośno, nosi narodowe stroje - odświętne i zdobne, je thukpę i momo potrawy w tybetańskich restauracjach, śpiewa pieśni i piosenki - o przywiązaniu do ziemi i jej bohaterach. To takie opozycyjne świętowanie przez podkreślanie narodowych właściwości. Być może wyrosłe, w mierze jakiejś, z dramatycznego protestu.

W Chinach obowiązuje piętrowa odpowiedzialność zbiorowa. Urzędnicy są karani, jeśli na ich terenie dochodzi do samospalenia. Ci sami urzędnicy pospiesznie i gorliwie karzą rodzinę człowieka, który dokonał autokremacji. W tej sprawie także życie społeczne regulowane jest specjalnymi prawami: rodzina,

${ }^{5}$ Thich Nhat Hanh: W poszukiwaniu wroga człowieka. Do Czcigodnego Martina Luthera Kinga. Dostępne w Internecie: https://www.hfhr.org.pl/tybet_old/raport.php?raport_id=1517 [data dostępu: 18.11.2019].

${ }^{6}$ Oser: Niewidoczny Tybet. Przeł. A. Kozieł. Warszawa 2013, s. 262.

7 Tamże, s. 306. 
wioska i klasztor są uznani współwinnymi i zostają skazani. Oczywiście zasada zbiorowej odpowiedzialności skutkuje w każdej społeczności relacjami opartymi na wzajemnej podejrzliwości, donosicielstwie - rozbija solidarność prześladowanych. Kary mają być dotkliwe, więc rodzinie zakazuje się podróżowania albo odbiera się jej z trudem uzyskane urzędowe pozwolenia: na prowadzenie herbaciarni, na budowę czegokolwiek, na zakup maszyny. Nęka się wszystkich: przesłuchaniami, inwigilacją, aresztem, czasem śmiercią.

\section{Zło dobrem trzeba nakrywać}

Często rozmawiam z mniszką Sangmo. I słyszę, jak powtarza, że zło tylko samo z siebie gaśnie, a my pozostajemy w przekonaniu, żeśmy coś uczynili przeciwko niemu. - Zło i dobro są częścią przyrody. Człowiek tak naprawdę ma tylko pozorny na nie wpływ. Człowiek ma/może mieć tylko wpływ na siebie - mówi cicho Sangmo.

Rozumienie zła w buddyzmie jest trudną figurą dla zachodniego umysłu. Zło ma podobną wartość, jaką niesie... pomyłka. Przy założeniu, a takie się czyni, że wszystkie istoty w gruncie rzeczy są doskonałe, zło jest tylko pochodną nieświadomości, pożądania, nienawiści - reakcją splamionego umysłu, który zakrywa przed sobą prawdę absolutną. Każda istota ma w sobie doskonałość natury buddy, tak jak każde ziarnko sezamu kryje olej. Trzeba pozbyć się negatywności, żeby tę doskonałość odsłonić. Fałsz nie jest prawdziwym bytem, jest tylko pomyłką - błędnym rozumieniem rzeczywistości. Zło zatem istnieje jako iluzja, nie istnieje naprawdę, bo nie broni się swoją niezależną wartością. Zło, czyli czyny i myśli, które prowadzą do cierpienia, jest zapomnieniem o dobru, czyli o czynach i myślach, które wynikają z pierwotnej natury buddy, która mieszka w każdym z nas, i które przynoszą szczęście.

Nie oznacza to, że buddyzm neguje potrzebę, konieczność poszukiwania praktycznych środków zaradczych, gdy pojawiają się sytuacje takich wymagające. Skoro istoty doświadczają cierpienia, należy je rozproszyć, nawet jeśli jest iluzoryczne. Przemocy, złu trzeba się przeciwstawiać. Naturalnie, pozostaje pytanie, jak to czynić? Buddyści nie mają wątpliwości, że w odpowiedzi nie można sięgać po przemoc. I nie mają wątpliwości, że najistotniejszą zmianą jest zmiana postawy. Przecież główną przyczyną przemocy jest chciwość, nienawiść, a te pochodzą z egoizmu, z przywiązania do ,ja”. Złe rzeczy, które spotykają ludzi od ludzi, wyrastają z negatywnych stanów umysłu, z ignorancji. 
Więc może już czas zacząć myśleć podobnie - o swojej przemianie dla dobra i o wspólnocie ludzkiej? Może prawo dla wszystkich i wszędzie winno być jednakie? Może dobro i zło winny być wszędzie i przez wszystkich jednako rozumiane? Może czas zacząć myśleć o wspólnocie ludzkiej miast o narodach i państwach? A może, wreszcie, pora już budować globalne prawo, oparte na zabsolutyzowanym, a nie relatywnym, rozróżnieniu dobra i zła - globalne prawo jednakie dla każdego?

Po pierwsze, zgódźmy się wszyscy, że czynienie zła jest zabronione: używanie przemocy fizycznej jest nieakceptowane przez ludzkość. Prawem zabrońmy prowadzenia wojen, zabijania. Po drugie, przyjmijmy globalną, ludzką odpowiedzialność za przeciwstawianie się złu, gdy ono się dzieje. Nie przyglądajmy się zbrodni, przeciwdziałajmy jej. Po trzecie, piętnujmy sprawców zła moralnie i karajmy ich zgodnie z nowym, globalnym, bezprzemocowym prawem - równym wszędzie i dla każdego.

Jeszcze na chwilę wróćmy do nauk Pemy Chödrön. Powiada ona, że wojna i (s)pokój rodzą się w człowieczym sercu. Serce zamknięte i serce otwarte są źródłem wszelkich implikacji. Potrzebujemy odwagi, by zamknięte serce otworzyć. Potrzebujemy odwagi, by serca nie zamykać. Kiedy czujemy zagrożenie, zamykamy nasze serce. A co się wydarzy, jeśli tak nie postąpimy? Będziemy czuć niepokój. I tu właśnie otwiera się miejsce dla odwagi: by znaleźć miękki, otwarty punkt we własnym sercu, choćby najmniejszy, i umieć w tym punkcie trwać niezależnie od morza niepokoju wokół. Serce zamyka się zawsze przez strach. Znajdując choćby najmniejszy punkt dobra, leczymy własne serce, zamieniamy strach w miłość.

Nauczycielka proponuje taką praktykę. Wyobraź sobie sytuację, która wywołuje twoją niechęć. Staraj się nie myśleć o niej, nie rozważać, tylko poczuć ją. Poczuj ten dyskomfort, tę nieprzyjemność i bądź z tym uczuciem. Zamknij oczy i oddychaj. I wtedy połącz się z innymi ludźmi, którzy tak samo jak ty odczuwają niechęci. Wdychaj do tego negatywnego uczucia i wydychaj ulgę. Zrób to zawsze, kiedy powstaną agresywne myśli, kiedy poczujesz ból wynikający z twojej niechęci. Ani się nie pozbywasz silnych emocji, ani w nich się nie zagłębiasz. Uczysz się zamieszkać w tym doświadczeniu bez nabudowywania tegoż i bez umniejszania. Jesteś w nim przez obecność, a nie przez zaangażowanie. Kiedykolwiek odczujesz żądło bólu, zatrzymaj myśl, oddychaj świadomie, kilka razy - niechaj to będzie przerwa, śluza do innego niż nawykowe myślenie. Nie bój się utraty poczucia bezpieczeństwa. Oddechem przechodzisz przez. I brakiem myśli.

Jasne, że to nie jest bezpośrednie rozwiązanie dla konfliktów zbiorowych. Ale jest to rozwiązanie dla każdej jednej i każdego jednego z nas. I takie prowadzi do globalnej zmiany. To, jak pracujemy z naszymi umysłami dziś, jak uczymy się otwierać nasze serca na drugich - to z pewnością ma i mieć będzie wpływ 
na życie na naszej planecie. Twoje bezpieczeństwo jest oparte na twojej miłości i twoim współczuciu. I to jest nowe dla świata, to jest nowa cywilizacja.

Warszawa, 27.08.2019

P.S.

Pytano nas, uczestniczących w konferencji ${ }^{8}$, dlaczego piszemy o konfliktach, problemach, zagrożeniach. Za siebie odpowiadam. Bo nie mogę o tym nie pisać. Bo mnie to obchodzi, czyli dotyczy. Bo przez pisanie pokazuję innym i wierzę, że sprawiam, że ich także będzie to obchodziło, dotyczyło. Bo jest to mój prywatny sposób na minimalne przeciwstawianie się złu.

Przez lata pisałam o zagładzie Żydów - pokazywałam przeszłość, którą odkrywałam dla siebie i dla innych. Przez ostatnie 10 lat jeździłam do tybetańskich osiedli w Indiach i uczyłam się uchodźczego losu wygnańców, żeby opowiedzieć o złu, którego doświadczają od prawie 70 lat. Dostrzeżone jest widoczne. Niezauważane jakby nie istniało. Od 10 lat próbuję zbliżyć się do rozumienia postawy Tybetańczyków wobec ich kulturowej i narodowej zagłady - wobec okrucieństwa i zbrodni (jakże odmiennej postawy od żydowskiej). Pisanie jest - tak myślę namiastką uczestniczenia $\mathrm{w}$, a także próbą nakrywania zła dobrem.

Hanka GruPińska - pisze i uczy. Współpracowała z pismami podziemnymi, współzałożyła poznański „Czas Kultury”. W latach 90. mieszkała w Izraelu. Jest autorką książek: Najtrudniej jest spotkać Lilit, Ciagle po kole, Odczytanie listy, Buntownicy, 12 opowieści żydowskich. Przez wiele lat zajmowała się historią zagłady Żydów i kulturą współczesnego Izraela. Przez ostatnie dziesięć przyglądała się losom Tybetańczyków. Opowiada o tym w swojej najnowszej książce Dalekowysoko, która ukazała się w sierpniu 2020.

8 Tekst został napisany do publikacji podsumowującej Międzynarodową Konferencję Edukacyjną pt. „Auschwitz - Nigdy więcej! - Czy na pewno?”, która odbyła się w Państwowym Muzeum Auschwitz-Birkenau 14 lipca 2019 r. 